Fixed Point Theory, 22(2021), No. 1, 75-82

DOI: $10.24193 /$ fpt-ro.2021.1.05

http://www.math.ubbcluj.ro/ nodeacj/sfptcj.html

\title{
A NOTE ON BEST PROXIMITY POINT FOR S-CYCLIC MAPPINGS
}

\author{
ABDELHAFID BASSOU, TAOUFIK SABAR AND AAMRI MOHAMED
}

Laboratory of Algebra, Analysis and Applications (L3A), Departement of Mathematics and Computer Science, Faculty of Sciences Ben M'sik, Hassan II University of Casablanca, P.B 7955 Sidi Othmane, Casablanca, Morocco

E-mail: hbassou@gmail.com (Corresponding author); sabarsaw@gmail.com; aamrimohamed82@gmail.com

Abstract. In this note, we introduce the new class of $S$ - cyclic mappings and prove some best proximity point thereof. Since $S-$ cyclic mappings generalize the ordinary cyclic mappings, our results extend and improve some best proximity results for cyclic mappings.

Key Words and Phrases: S-cyclic mapping, best proximity point.

2020 Mathematics Subject Classification: 47H09, 47H10, 54H25.

\section{Acknowledgments.}

- Research supported by a National Centre of Scientific and Technological Research grant.

- The authors are grateful to the editor and the anonymous referees for their constructive comments, which have improved this paper.

\section{REFERENCES}

[1] A. Abkar, M. Gabeleh, Global optimal solutions of noncyclic mappings in metric spaces, J. Optim. Theory Appl., 153(2012), 298-305.

[2] A.A. Eldred, W.A. Kirk, P. Veeramani, Proximal normal structure and relatively nonexpansive mappings, Studia Math., 171(2005), 283-293.

[3] A.A. Eldred, V.S. Raj, P. Veeramani, On best proximity pair theorems for relatively $u$-continuous mappings, Nonlinear Anal. Theory, Methods \& Applications, 74(2011), no. 12, 3870-3875.

[4] A. Eldred, V.S. Raj, On common best proximity pair theorems, Acta Sci. Math. Szeged, 75(2009), 707-721.

[5] J. Markin, N. Shahzad, Best proximity points for relatively u-continuous mappings in Banach and Hyperconvex spaces, Abstract and Applied Analysis, Vol. 2013, art. ID 680186.

[6] V.S. Raj, A best proximity point theoremfor weakly contractive non-self-mappings, Nonlinear Anal. Theory, Methods \& Applications, 74(2011), no. 14, 4804-4808.

[7] T. Sabar, A. Bassou, M. Aamri, Best proximity point for tricyclic contractions in (S) convex metric spaces, International J. Mathematical Analysis, HIKARI Ltd, 12(2018), no. 6, 289-299.

[8] T. Sabar, M. Aamri, A. Bassou, Best proximity point of tricyclic contractions, Adv. Fixed Point Theory, $\mathbf{7}(2017)$, no. 4, 512-523. 
Received: January 17, 2019; Accepted: July 4, 2019. 